\title{
Clinical Role of Serum Lactic Dehydrogenase Assessment in Critically Ill Pediatric Patients with Sepsis
}

\author{
NAHLA A. MOHAMED, Ph.D.* and EMAN R. YOUNESS, M.D.** \\ The Department of Pediatrics, El Galaa Teaching Hospital, General Organization of Teaching Hospitals \& Institutes* and \\ Department of Medical Biochemistry, National Research Center**
}

\begin{abstract}
Background: Sepsis is a systemic inflammatory disorder that may be associated with higher rate of morbidity and mortality in pediatric patients admitted to intensive care unit with sepsis. Usage of different biomarker may helpful for early identification and appropriate management of sepsis.

Aim of Study: To investigated the role of serum lactic dehydrogenase (LDH) in prediction of sepsis in critical pediatric patients, and its relation with prognostic scoring systems.

Patients and Methods: A prospective cohort study was conducted at El Galaa Teaching Hospital between January 2020 and December 2020. A total of 168 pediatric patients were divided into the septic group ( 84 critically ill patients with sepsis from the pediatric intensive care unit (PICU)] and the control group (84 stable patients admitted to the in patient word). Demographic and clinical data were collected, routine laboratory investigation including LDH on admission and after 24 hours were performed. Pediatric Risk of Mortality III (PRISM III) Sequential Organ Failure Assessment (pSOFA) were assessed.
\end{abstract}

Results: The serum LDH level was significantly higher in septic than control $(p=0.000)$ and in non-survivor than survivor group $(p=0.000)$. Also, There was statistically significant between survivor and non-survivor as regarding length of hospital stay, pSOFA score and PRISM III score. There was statistically significant positive correlation between LDH, PRISM III $(r=0.842, p<0.001)$ and pSOFA $(r=0.785$, $p<0.001)$.

Conclusion: The study concluded that the LDH is a useful marker in predicting of sepsis in critically ill pediatric patients especially when combined with prognostic scoring systems.

Key Words: Lactate dehydrogenase - Sepsis - Pediatric intensive care unit - Pediatric Risk of Mortality III - Sequential organ failure assessment.

Correspondence to: Dr. Nahla A. Mohamed, The Department of Pediatrics, El Galaa Teaching Hospital, General Organization of Teaching Hospitals \& Institutes

\section{Introduction}

SEPSIS is a life-threatening health problem that may associated with increased mortality in children and young adult even in developed countries, it has been defined as a systemic inflammatory response syndrome (SIRS) caused by bloodstream infections or organ dysfunction caused by a host response deregulation to infection [1].

SIRS may be due to infectious and noninfectious causes. Pediatric SIRS is defined by abnormal temperature: Hyperthermia or hypothermia $\left(>38.5^{\circ} \mathrm{C}\right.$ or $\left.<36^{\circ} \mathrm{C}\right)$; or abnormal leukocyte count: elevated or depressed leucocytic count for age, or $>10 \%$ immature neutrophils, tachycardia or bradycardia, tachypnea [2] . Abnormal temperature and leukocyte count are essential for diagnosis of SIRS, while abnormal respiratory rates and heart rate are common in pediatrics may occur in clinical conditions and unnecessarily indicate SIRS [3] .

Biomarkers can play an important role in providing a timely diagnosis of sepsis, helping in distinguishing between infectious and noninfectious SIRS and the decision-making in the initial management [4]. In pediatrics, one of most commonly used biomarker to differentiate sepsis from non-infectious SIRS is serum lactic dehydrogenase (LDH) [5]. It's one of the enzyme involved in anaerobic metabolic pathway, its level increased in multiple clinical conditions associated with tissue damage [6]. Many studies suggested that significant elevation in serum LDH levels early in sepsis can be useful as a marker for reflecting the extent of tissue damage [7].

Elevated serum LDH in pediatric patients with sepsis reflect imbalance between lactate production and clearance [8]. Increased serum lactate levels 
in sepsis may occur through several mechanisms, including anaerobic glycolysis as result of impaired oxygen delivery to tissue as well as tissue hypo perfusion, stress as endogenous and exogenous catecholamines are highly associated with lactic acid production in sepsis, elevated bacterial load [9]. And decreased lactate clearance that induced by hepatic and renal dysfunction [10]

\section{Patients and Methods}

A prospective cohort study was conducted at El Galaa teaching hospital between January 2020 and December 2020 The study was carried out on 168 ill children, who were divided into 2 groups: Cases group (1): 84 critically ill children who were admitted to the PICU with sepsis and Control group (2): 84 stable control admitted to the inpatient word. Aiming to assess serum lactic dehydrogenase levels in predicting sepsis in pediatric critical patients, and also the relation between LDH and scoring systems (Pediatric Risk of Mortality (PRISM III), Pediatric Sequential Organ Failure Assessment pSOFA).

\section{Inclusion criteria:}

1- Age: 1 month-14 years old.

2- Sex: male or female.

3- Patients with sepsis (defined as SIRS in the presence of or as a result of suspected or documented infection) Goldstein et al. [11] admitted to the PICU.

\section{Exclusion criteria:}

1- Patients on steroids.

2- Patients known with metabolic disorders, chronic liver and kidney disease.

3- Death in less than 48 hours.

4- Patients with acute hemolytic anemia.

5- Post-operative patients.

\section{Ethical considerations:}

Informed consent was obtained willingly from all patients, control and/or their legal guardians before enrollment in the study. The ethics committee of General Organization of Teaching Hospital and Institutes approved the study design and conducted according to Helsinki declaration.

\section{All studied cases were subjected to the following:}

1-Full history and data including sex, age, primary diagnosis, history of chronic illness and chronic medication use and current medications.

2- Complete clinical and systemic examinations including vital signs especially heart rate, blood pressure and temperature, respiratory rate, conscious level of patients, presence of infection or sepsis.

3- Laboratory investigations on admission including: Complete Blood Counts (CBC), C-reactive protein (CRP), prothrombin time (PT), partial thromboplastin time (PTT), international normalized ratio (INR), potassium (K), sodium $(\mathrm{Na})$, Blood Urea Nitrogen (BUN), serum creatinine $(\mathrm{Cr})$, alanine transaminase (ALT), aspartate transaminase (AST), LDH (day 1) and after 24 hour (day 2).

4- System failure assessment (pSOFA score and PRISM III score). Use of mechanical ventilation.

5- Evaluation of patients outcome (death or improved), duration of hospital stay.

\section{Samples collection, LDH assay:}

$5 \mathrm{ml}$ of whole blood were collected from cases and controls by aseptic venipuncture for $\mathrm{LDH}$ assay on. Samples were immediately centrifuged and the serum was used for analysis on blood chemistry analyzer Dimension RXL MAX integrated chemistry system from Siemens Healthcare S.A.E, Germany.

\section{Statistical analysis:}

Data were collected, revised, coded and entered to the Statistical Package for Social Science (IBM SPSS) version 23. The quantitative data with parametric distribution were presented as mean, standard deviations and ranges while with non parametric distribution were presented as median with interquartile range (IQR). Also qualitative variables were presented as number and percentages. The comparison between groups regarding qualitative data was done by using Chi-square test and/or Fisher exact test when the expected count in any cell found less than 5. The comparison between two independent groups with quantitative data and parametric distribution was done by using Independent $t$-test and with non parametric distribution were done by using Mann-Whitney test. Comparison between two paired groups regarding non parametric data was done by using Wilcoxon Rank test. Spearman correlation coefficients were used to assess the correlation between two quantitative parameters in the same group. Univariate and multivariate logistic regression analysis was used to assess the predictors of cases group and their outcome. The confidence interval was set to $95 \%$ and the margin of error accepted was set to $5 \%$. So, the $p$-value was considered significant as the level of $<0.05$. 


\section{Results}

The present study included 168 patients ( 84 cases and 84 controls). Cases were collected from PICU and control group were recruited from general ward of El Galaa Teaching Hospital.

Table (1): Demographic and clinical data of cases and control groups.

\begin{tabular}{|c|c|c|c|}
\hline Variable & $\begin{array}{l}\text { Control } \\
\text { group } \\
\text { No. }=84\end{array}$ & $\begin{array}{c}\text { Cases } \\
\text { group } \\
\text { No.=84 }\end{array}$ & $\begin{array}{c}p- \\
\text { value }\end{array}$ \\
\hline \multicolumn{4}{|l|}{ Age in months: } \\
\hline Median (IQR) & $13(6-34)$ & $13(6-26)$ & 0.722 \\
\hline Range & $1-90$ & $1-122$ & \\
\hline \multicolumn{4}{|l|}{ Sex: } \\
\hline Male & $35(41.7 \%)$ & $42(50.0 \%)$ & 0.278 \\
\hline Female & $49(58.3 \%)$ & $42(50.0 \%)$ & \\
\hline \multicolumn{4}{|c|}{ Length of hospital stay in days: } \\
\hline Median (IQR) & $8(7-10)$ & $10(8-16)$ & 0.000 \\
\hline Range & $5-18$ & $5-34$ & \\
\hline \multicolumn{4}{|l|}{ Diagnosis: } \\
\hline Neurological disease & $4(4.8 \%)$ & $12(14.3 \%)$ & \\
\hline Cardiovascular disease & $0(0.0 \%)$ & $16(19.0 \%)$ & \\
\hline Respiratory disease & $28(33.3 \%)$ & $34(40.5 \%)$ & \\
\hline Blood born infection & $0(0.0 \%)$ & $14(16.7 \%)$ & \\
\hline Gastrointestinal disease & $39(46.4 \%)$ & $8(9.5 \%)$ & \\
\hline Renal infection & $8(9.5 \%)$ & $0(0.0 \%)$ & \\
\hline Others & $5(6.0 \%)$ & $0(0.0 \%)$ & \\
\hline \multicolumn{4}{|l|}{ Outcome: } \\
\hline Survival & $84(100.0 \%)$ & $50(59.5 \%)$ & 0.000 \\
\hline Non-survival & $0(0.0 \%)$ & $34(40.5 \%)$ & \\
\hline \multicolumn{4}{|l|}{ Mechanical ventilation: } \\
\hline No & $84(100.0 \%)$ & $62(73.8 \%)$ & 0.000 \\
\hline Yes & $0(0.0 \%)$ & $22(26.2 \%)$ & \\
\hline \multicolumn{4}{|l|}{ SOFA: } \\
\hline Median (IQR) & $5.5(4-7)$ & $10(7-17)$ & 0.000 \\
\hline Range & $2-11$ & $4-22$ & \\
\hline \multicolumn{4}{|l|}{ PRISM III: } \\
\hline Median (IQR) & $22.5(18-28)$ & $44.5(23-62)$ & 0.000 \\
\hline Range & $3-48$ & $10-71$ & \\
\hline
\end{tabular}

$p$-value $>0.05$ : Non significant. $p$-value $<0.05$ : Significant. $p$-value $<0.01$ : Highly significant

In the cases group, median age was 13 (6-26) months, $50.0 \%$ were males, $50.0 \%$ were females. In the controls group, mean age was 13 (6-34) months, $41.7 \%$ were males, and $58.3 \%$ were females. There was significant difference in both groups regarding length of hospital stay, use of mechanical ventilation and outcome, pSOFA score and PRISM III score $(p$-value $=0.000)$.
Table (2): Laboratory data of cases and control groups

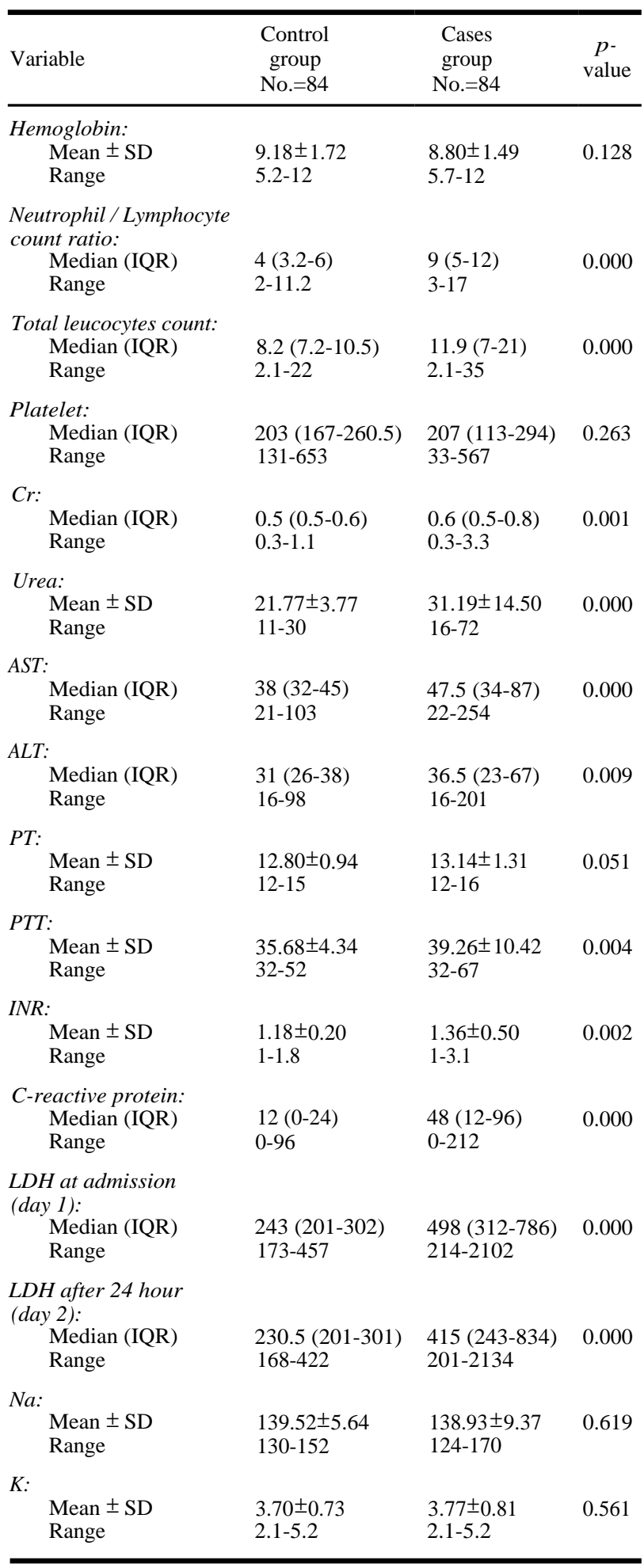

There was significant difference between both groups regarding granulocyte/lymphocyte ratio, total leucocytic count (TLC), creatinine (Cr), Urea, aspartate transaminase (AST), alanine transaminase (ALT), partial thromboplastin time (PTT), international normalized ratio (INR), C-reactive protein (CRP), lactate dehydrogenase (LDH) on day $1 \& 2$. 
Table (3): Correlation of LDH at day 1 with the other studied parameters in Cases group.

\begin{tabular}{lcc}
\hline & \multicolumn{2}{c}{ LDH at admission (day 1) } \\
\cline { 2 - 3 } Variable & $r$ & $p$-value \\
\cline { 2 - 3 } Age in months & $0.246^{*}$ & 0.024 \\
Length of hospital stay in days & $0.548^{* *}$ & 0.000 \\
Hemoglobin & $-0.494^{* *}$ & 0.000 \\
Neutrophil / Lymphocyte count ratio & $0.774^{* *}$ & 0.000 \\
Total leucocytes count & $0.483^{* *}$ & 0.000 \\
Platelet & $-0.593^{* *}$ & 0.000 \\
Cr & $0.462^{* *}$ & 0.000 \\
Urea & $0.623^{* *}$ & 0.000 \\
AST & $0.754^{* *}$ & 0.000 \\
ALT & $0.771^{* *}$ & 0.000 \\
PT & $0.366^{* *}$ & 0.001 \\
PTT & $0.415^{* *}$ & 0.000 \\
INR & $0.403^{* *}$ & 0.000 \\
C reactive protein & $0.818^{* *}$ & 0.000 \\
pSOFA & $0.785^{* *}$ & 0.000 \\
PRISM III & $0.842^{* *}$ & 0.000 \\
Na & 0.064 & 0.565 \\
K & $0.320^{* *}$ & 0.003 \\
\hline
\end{tabular}

$p$-value $>0.05$ : Non significant. $\quad p$-value $<0.05$ : Significant. $\quad p$-value $<0.01$ : Highly significant Spearman correlation coefficient.

There was statistically significant correlation between lactate dehydrogenase (LDH) at admission and hemoglobin, granulocyte/lymphocyte ratio, total leucocytic count (TLC), creatinine (Cr), Urea,
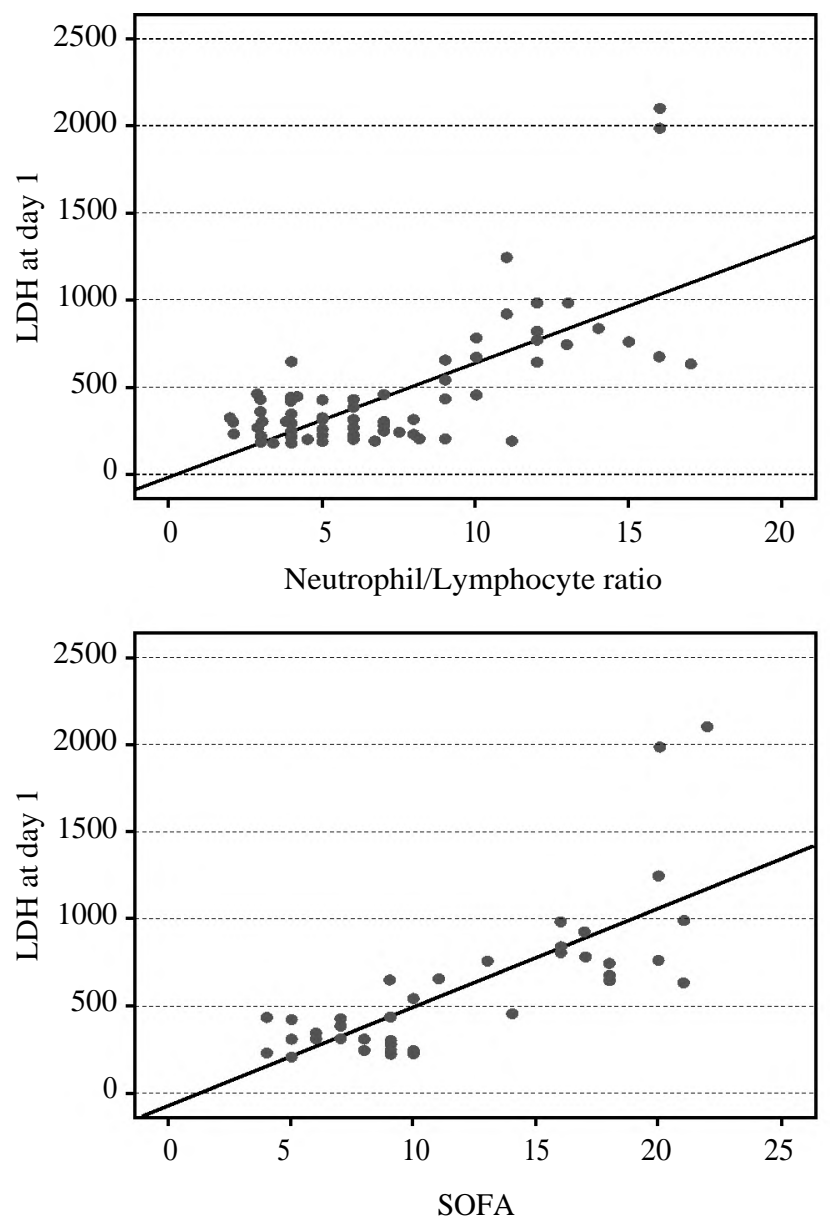

aspartate transaminase (AST), alanine transaminase (ALT), partial thromboplastin time (PTT), international normalized ratio (INR), C-reactive protein (CRP), serum potassium in cases group.
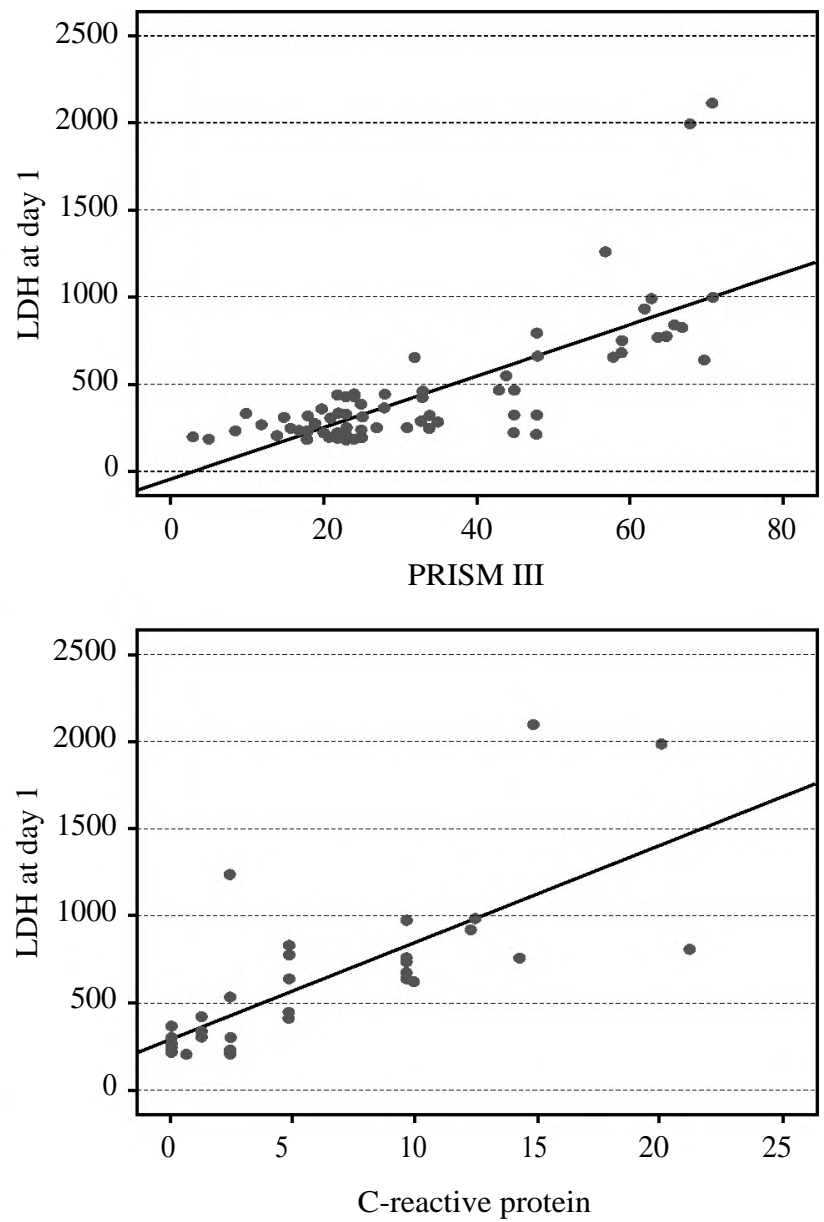

Fig. (1): Correlation of LDH on admission with neutrophil /lymphocyte count ratio, CRP and scoring system (pSOFA, PRISM III). 
Table (4): Relation of outcome with demographic and clinical data in cases group.

\begin{tabular}{|c|c|c|c|}
\hline Variable & $\begin{array}{l}\text { Survival } \\
\text { No. }=50\end{array}$ & $\begin{array}{c}\text { Non-survival } \\
\text { No. }=34\end{array}$ & $p$-value \\
\hline $\begin{array}{l}\text { Age in months: } \\
\text { Median (IQR) } \\
\text { Range }\end{array}$ & $\begin{array}{l}13(6-27) \\
1-122\end{array}$ & $\begin{array}{l}13(9-25) \\
2-65\end{array}$ & 0.584 \\
\hline $\begin{array}{l}\text { Sex: } \\
\quad \text { Male } \\
\text { Female }\end{array}$ & $\begin{array}{l}20(40.0 \%) \\
30(60.0 \%)\end{array}$ & $\begin{array}{l}22(64.7 \%) \\
12(35.3 \%)\end{array}$ & 0.026 \\
\hline $\begin{array}{l}\text { Length of hospital stay in da } \\
\text { Median (IQR) } \\
\text { Range }\end{array}$ & $\begin{array}{l}9(7-12) \\
5-18\end{array}$ & $\begin{array}{l}16(10-25) \\
8-34\end{array}$ & 0.000 \\
\hline $\begin{array}{l}\text { Diagnosis: } \\
\text { Neurological disease } \\
\text { Cardiovascular disease } \\
\text { Respiratory disease } \\
\text { Blood born infection }\end{array}$ & $\begin{array}{l}8(16.0 \%) \\
8(16.0 \%) \\
20(40.0 \%) \\
8(16.0 \%)\end{array}$ & $\begin{array}{l}4(11.8 \%) \\
8(23.5 \%) \\
14(41.2 \%) \\
6(17.6 \%)\end{array}$ & 0.792 \\
\hline $\begin{array}{l}\text { Mechanical ventilation: } \\
\text { No } \\
\text { Yes }\end{array}$ & $\begin{array}{l}44(88.0 \%) \\
6(12.0 \%)\end{array}$ & $\begin{array}{l}18(52.9 \%) \\
16(47.1 \%)\end{array}$ & 0.000 \\
\hline $\begin{array}{l}\text { SOFA: } \\
\text { Median (IQR) } \\
\text { Range }\end{array}$ & $\begin{array}{l}8(6-9) \\
4-14\end{array}$ & $\begin{array}{l}18(17-20) \\
16-22\end{array}$ & 0.000 \\
\hline $\begin{array}{l}\text { PRISM III: } \\
\quad \text { Median (IQR) } \\
\quad \text { Range }\end{array}$ & $\begin{array}{l}31(22-34) \\
10-65\end{array}$ & $\begin{array}{l}63(59-67) \\
48-71\end{array}$ & 0.000 \\
\hline
\end{tabular}

$p$-value $>0.05$ : Non significant. $\quad p$-value $<0.05$ : Significant. $\quad p$-value $<0.01$ : Highly sign.

There was statistically significant between survivor and non-survivor as regarding length of

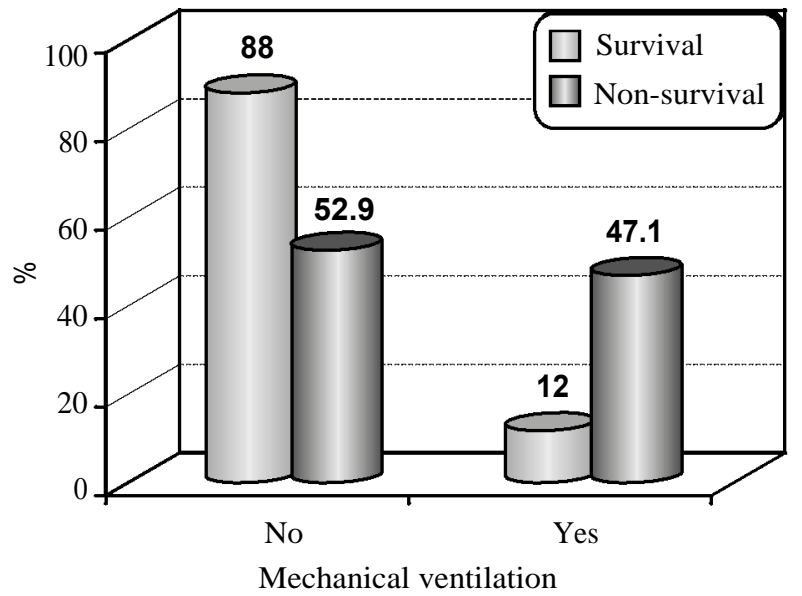

hospital stay, mechanical ventilation, pSOFA score and PRISM III score.

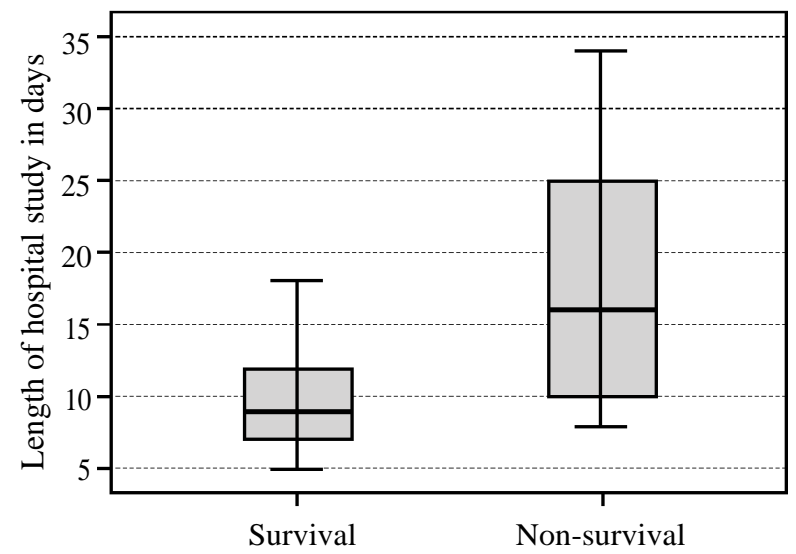

Fig. (2): Relation of outcome with length of hospital stay and mechanical ventilation in studied cases group.

The previous ROC curve shows that the best cut off point between cases and controls regarding granulocyte/lymphocyte ratio was found $>7.5$ with sensitivity of $61.90 \%$, specificity of $90.48 \%$ and AUC of $81.8 \%$, regarding C-reactive protein was found $>24$ with sensitivity of $52.38 \%$, specificity of $82.14 \%$ and AUC of $70.0 \%$, regarding SOFA score was found $>8$ with sensitivity of $66.67 \%$, specificity of $88.10 \%$ and AUC of $84.0 \%$, regarding PRISM3 was found $>28$ with sensitivity of $71.43 \%$, specificity of $78.57 \%$ and AUC of $78.7 \%$ while regarding $\mathrm{LDH}$ at day 1 the best cut off point was found $>302$ with sensitivity $80.95 \%$, specificity $76.19 \%$ and AUC $84.5 \%$. 
Table (5): Relation of outcome with laboratory data in cases group.

\begin{tabular}{|c|c|c|c|}
\hline Variable & $\begin{array}{l}\text { Survival } \\
\text { No. }=50\end{array}$ & $\begin{array}{c}\text { Non-survival } \\
\text { No. }=84\end{array}$ & $\begin{array}{c}p- \\
\text { value }\end{array}$ \\
\hline \multicolumn{4}{|l|}{ Hemoglobin: } \\
\hline Mean \pm SD & $9.27 \pm 1.47$ & $8.10 \pm 1.25$ & \multirow[t]{2}{*}{0.000} \\
\hline Range & $6.3-12$ & $5.7-10.2$ & \\
\hline \multicolumn{4}{|c|}{$\begin{array}{l}\text { Neutrophil / Lymphocyte } \\
\text { count ratio: }\end{array}$} \\
\hline Median (IQR) & $6(4.2-8)$ & $13(11-15)$ & \multirow[t]{2}{*}{0.000} \\
\hline Range & $3-12$ & $10-17$ & \\
\hline \multicolumn{4}{|c|}{ Total leucocytes count: } \\
\hline Median (IQR) & $9.5(6.2-12)$ & $21(18-25)$ & \multirow[t]{2}{*}{0.000} \\
\hline Range & $2.1-21$ & $3.2-35$ & \\
\hline \multicolumn{4}{|l|}{ Platelet: } \\
\hline Median (IQR) & $234(201-432)$ & $101(68-151)$ & \multirow[t]{2}{*}{0.000} \\
\hline Range & $42-567$ & $33-534$ & \\
\hline \multicolumn{4}{|l|}{$C r:$} \\
\hline Median (IQR) & $0.6(0.5-0.6)$ & $0.7(0.6-1.7)$ & \multirow[t]{2}{*}{0.000} \\
\hline Range & $0.3-1.9$ & $0.5-3.3$ & \\
\hline \multicolumn{4}{|l|}{ Urea: } \\
\hline Mean \pm SD & $25.28 \pm 9.06$ & $39.88 \pm 16.61$ & \multirow[t]{2}{*}{0.000} \\
\hline Range & $16-57$ & $19-72$ & \\
\hline \multicolumn{4}{|l|}{ AST: } \\
\hline Median (IQR) & $43(33-48)$ & $102(67-133)$ & \multirow[t]{2}{*}{0.000} \\
\hline Range & $22-125$ & $33-254$ & \\
\hline \multicolumn{4}{|l|}{$A L T:$} \\
\hline Median (IQR) & $27(21-35)$ & $67(48-98)$ & \multirow[t]{2}{*}{0.000} \\
\hline Range & $16-98$ & $27-201$ & \\
\hline \multicolumn{4}{|l|}{$P T:$} \\
\hline Mean $\pm S D$ & $12.88 \pm 1.12$ & $13.53 \pm 1.48$ & \multirow[t]{2}{*}{0.025} \\
\hline Range & $12-16$ & $12-16$ & \\
\hline \multicolumn{4}{|l|}{ PTT: } \\
\hline Mean \pm SD & $38.24 \pm 9.55$ & $40.76 \pm 11.57$ & \multirow[t]{2}{*}{0.278} \\
\hline Range & $32-67$ & $33-67$ & \\
\hline \multicolumn{4}{|l|}{$I N R:$} \\
\hline Mean \pm SD & $1.25 \pm 0.30$ & $1.53 \pm 0.67$ & \multirow[t]{2}{*}{0.011} \\
\hline Range & $1-2.1$ & $1-3.1$ & \\
\hline \multicolumn{4}{|l|}{$C$-reactive protein: } \\
\hline Median (IQR) & $12(0-24)$ & $96(96-124)$ & 0.000 \\
\hline Range & $0-96$ & $24-212$ & \\
\hline LDH at (day 1): & & & \\
\hline Median (IQR) & $312(245-432)$ & $834(745-980)$ & 0.000 \\
\hline Range & $214-765$ & $629-2102$ & \\
\hline LDH at (day 2): & & & \\
\hline Median (IQR) & $256(209-387)$ & 856 (754-1267) & 0.000 \\
\hline Range & $201-701$ & $627-2134$ & \\
\hline$N a:$ & & & \\
\hline Mean \pm SD & $140.92 \pm 11.24$ & $136.00 \pm 4.29$ & 0.017 \\
\hline Range & $133-170$ & $124-145$ & \\
\hline$K:$ & & & \\
\hline Mean \pm SD & $3.47 \pm 0.70$ & $4.20 \pm 0.76$ & 0.000 \\
\hline Range & $2.2-4.5$ & $2.1-5.2$ & \\
\hline
\end{tabular}

$p$-value $>0.05$ : Non significant.

$p$-value $<0.05$ : Significant.

$p$-value $<0.01$ : Highly significant

$\bullet:$ Independent $t$-test.

$\neq$ : Mann-Whitney test.
The previous univariate logistic regression analysis shows that all the previous parameters were associated with sepsis with $p$-value $<0.001$; also the multivariate analysis shows that the most important predictors for sepsis was found $\mathrm{LDH}$ at day $1>302$ with OR $(95 \% \mathrm{CI})$ of 8.600 (3.358$22.028)$ followed by SOFA $>8$ with OR $(95 \% \mathrm{CI})$ 6.871 (2.274-20.763) followed by total leucocytes count $>11.4$ with OR(95\% CI) of 5.072 (1.45417.697) and lastly INR $>1.6$ with OR( $95 \% \mathrm{CI})$ of $0.139(0.023-0.828)$.

The previous table shows that the outcome of the studied patients was associated with male gender with $p$-value $=0.028$ and OR $(95 \% \mathrm{CI})$ of 2.750 (1.115-6.782).
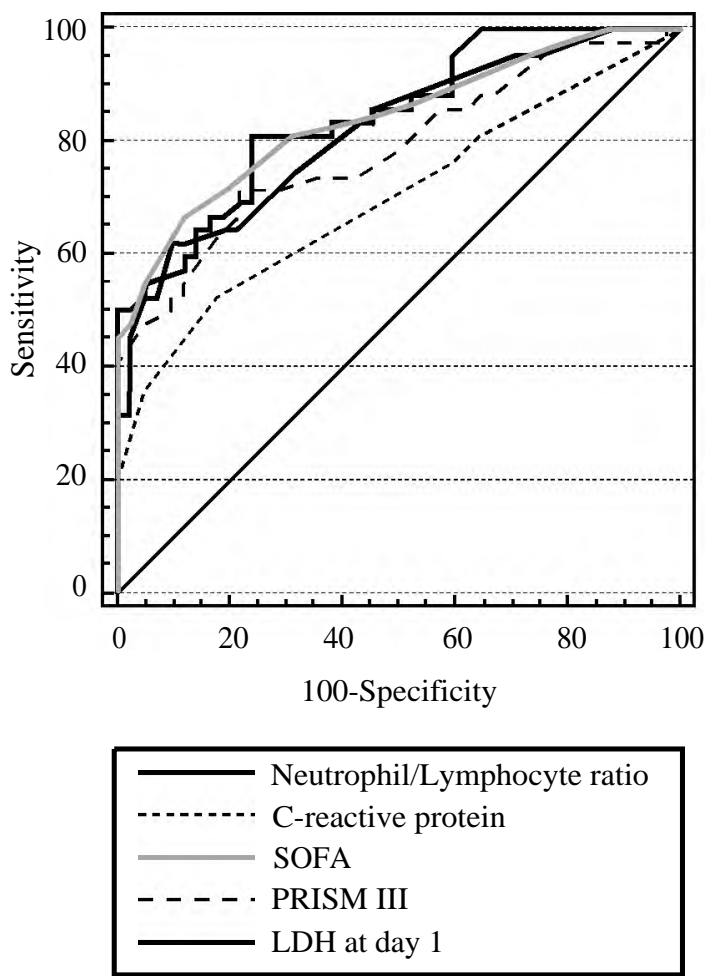

Fig. (3): Receiver operating characteristic curve (ROC) for the studied parameters as diagnostic markers for sepsis in studied groups.

\begin{tabular}{lllllll}
\hline Variables & $\begin{array}{c}\text { Cut } \\
\text { off } \\
\text { point }\end{array}$ & AUC & $\begin{array}{c}\text { Sensi- } \\
\text { tivity }\end{array}$ & $\begin{array}{c}\text { Speci- } \\
\text { ficity }\end{array}$ & $+\mathrm{PV}$ & -PV \\
\hline $\begin{array}{l}\text { Neutrophil/ } \\
\text { Lymphocyte }\end{array}$ & $>7.5$ & 0.818 & 61.90 & 90.48 & 86.7 & 70.4 \\
$\begin{array}{r}\text { ratio } \\
\text { C-reactive }\end{array}$ & $>24$ & 0.700 & 52.38 & 82.14 & 74.6 & 63.3 \\
$\quad$ protein & $>8$ & 0.840 & 66.67 & 88.10 & 84.8 & 72.5 \\
$\begin{array}{l}\text { SOFA } \\
\text { PRISM3 }\end{array}$ & $>28$ & 0.787 & 71.43 & 78.57 & 76.9 & 73.3 \\
LDH at day 1 & $>302$ & 0.845 & 80.95 & 76.19 & 80.95 & 76.19 \\
\hline
\end{tabular}


Table (6): Univariate and multivariate logistic regression analysis for predictors of cases group.

\begin{tabular}{|c|c|c|c|c|c|c|c|c|}
\hline \multirow{3}{*}{ Variable } & \multicolumn{4}{|c|}{ Univariate } & \multicolumn{4}{|c|}{ Univariate } \\
\hline & \multirow{2}{*}{$\begin{array}{c}p- \\
\text { value }\end{array}$} & \multirow{2}{*}{$\begin{array}{l}\text { Odds ratio } \\
\text { (OR) }\end{array}$} & \multicolumn{2}{|c|}{$95 \%$ C.I. for OR } & \multirow{2}{*}{$\begin{array}{c}p- \\
\text { value }\end{array}$} & \multirow{2}{*}{$\begin{array}{l}\text { Odds ratio } \\
\text { (OR) }\end{array}$} & \multicolumn{2}{|c|}{$95 \%$ C.I. for OR } \\
\hline & & & Lower & Upper & & & Lower & Upper \\
\hline Length of hospital stay in days $>11$ & 0.000 & 7.848 & 3.368 & 18.284 & & & & \\
\hline Neutrophil / Lymphocyte ratio > 7.5 & 0.000 & 15.437 & 6.590 & 36.164 & 0.011 & 5.072 & 1.454 & 17.697 \\
\hline Total leucocytes count $>11.4$ & 0.000 & 6.667 & 3.250 & 13.673 & 0.094 & 2.532 & 0.854 & 7.504 \\
\hline Creatinin $>0.6$ & 0.003 & 2.750 & 1.397 & 5.412 & & & & \\
\hline Urea $>24$ & 0.000 & 6.906 & 3.428 & 13.912 & - & - & - & - \\
\hline AST $>49$ & 0.000 & 6.727 & 3.062 & 14.779 & - & - & - & - \\
\hline ALT $>44$ & 0.000 & 6.113 & 2.780 & 13.440 & - & - & - & - \\
\hline PTT >42 & 0.002 & 4.613 & 1.762 & 12.076 & & & & \\
\hline INR > 1.6 & 0.001 & 6.250 & 2.034 & 19.207 & 0.030 & 0.139 & 0.023 & 0.828 \\
\hline
\end{tabular}

Table (7): Univariate logistic regression analysis for predictors of outcome in cases group.

\begin{tabular}{|c|c|c|c|c|c|c|c|}
\hline \multirow{2}{*}{ Variable } & \multirow{2}{*}{$\mathrm{B}$} & \multirow{2}{*}{ S.E. } & \multirow{2}{*}{ Wald } & \multirow{2}{*}{$\begin{array}{c}p \text { - } \\
\text { value }\end{array}$} & \multirow{2}{*}{$\begin{array}{l}\text { Odds ratio } \\
\quad(\mathrm{OR})\end{array}$} & \multicolumn{2}{|c|}{$95 \%$ C.I. for $\mathrm{OR}$} \\
\hline & & & & & & Lower & Upper \\
\hline Sex & -1.012 & 0.461 & 4.824 & 0.028 & 0.364 & 0.147 & 0.897 \\
\hline Length of hospital stay in days $>9$ & 2.420 & 0.606 & 15.977 & 0.000 & 11.250 & 3.433 & 36.862 \\
\hline Mechanical ventilation & 1.875 & 0.554 & 11.431 & 0.001 & 6.519 & 2.199 & 19.325 \\
\hline Hemoglobin $<=7.8$ & 1.776 & 0.517 & 11.820 & 0.001 & 5.906 & 2.146 & 16.257 \\
\hline Neutrophil $\backslash$ lymphocyte ratio $>9$ & 1.525 & 0.420 & 13.176 & 0.000 & 4.597 & 2.017 & 10.474 \\
\hline Total leucocytes count $>13.2$ & 3.533 & 0.626 & 31.858 & 0.000 & 34.222 & 10.035 & 116.706 \\
\hline Platelet $<=151$ & 3.621 & 0.660 & 30.128 & 0.000 & 37.375 & 10.258 & 136.181 \\
\hline Creatinine $>0.6$ & 2.028 & 0.501 & 16.367 & 0.000 & 7.600 & 2.845 & 20.302 \\
\hline
\end{tabular}

\section{Discussion}

Many potential biomarkers and scores come into focus in the last decade for early diagnosis, risk stratification and evaluation of critically ill patient's prognosis in the Emergency Department [12]. Diagnosis of critically ill patients with suspected sepsis is challenging and complex, early identification and immediate management are crucial to increase the chances of favorable outcome of septic patients, depending on clinical evaluation alone is often insufficient for an early diagnosis of sepsis [13]

Serum lactic dehydrogenase is a cytoplasmic enzyme that is present in different body tissues especially muscle, liver and kidney contain high concentration of LDH as well as red blood cells also contain moderate concentrations of this enzyme. This differential expression of LDH is the basis of its importance as a clinical diagnostic biomarker [14]. Elevated serum LDH is associated with tissue breakdown. Consequently, present in several clinical conditions, such as hemolysis, cancers, severe infections and sepsis [15]. Measuring the LDH level for critically ill patients with suspected sepsis, provides useful information on the severity of the condition and enables monitoring progression of disease [4].
No single biomarkers of sepsis can be used to distinguish sepsis from other inflammatory conditions [16]. The most widely used biomarkers in critically ill patients with suspected sepsis are Creactive protein (CRP), procalcitonin (PCT), lactate another biological simple inexpensive marker as well as granulocyte and lymphocyte count ratio [17].

The present study demonstrated that the LDH level was significantly increased in cases than controls as well as in non-surviving critically ill patients with sepsis. The cutoff value of $>302 \mathrm{gL}$ was a predictor for sepsis with a sensitivity of $80.95 \%$ and specificity of $76.19 \%$.

This is in agreement with Aharon et al. [15] study reported a significant increase in serum level of LDH at the onset of sepsis symptoms and suggested that presence of high serum LDH at admission required through investigations for sever underlying disease especially cancer and severe infections and can be consider as independent predictor factor of morbidity and mortality. Also Wacharasint et al. [18] assumed that patients with LDH levels in the normal-range (between 1.4 and $2.3 \mathrm{mmol} / \mathrm{L}$ ) had markedly increasing risk of organ failure and higher mortality compared with patients who had LDH levels less than $1.4 \mathrm{mmol} / \mathrm{L}$. 
Wasserman et al. [19] demonstrated that the finding of very high isolated $\mathrm{LDH}$ in admitted medical patients is a marker of unfavorable outcome and very high isolated LDH is an important distinguishing marker for the presence of a limited list of underlying diseases, mostly infections, particularly pneumonia, cancer ( $27 \%$ vs. $4 \%$, in the $\mathrm{LDH}$ group and controls respectively, $p<0.0001$ ), liver metastases ( $14 \%$ vs. $3 \%, p<0.0001)$, and hematologic malignancies ( $5 \%$ vs. $0 \%, p=0.00019)$. Also Hendya et al. [20] study reported that LDH, albumin, CRP, and neutrophils\% are important serum markers in determining community acquired pneumonia prognosis and they should be performed on admission to predict probable complications and outcome of patients with community acquired pneumonia. This can be explained by serum lactate dehydrogenase is present in almost all tissues So, during tissue damage LDH will released from most of this tissues and lead to elevated serum LDH level as well as decreased clearance in some cases such as septic conditions [21]

But in contrary Helliksson et al. [22] suggested that presence of LDH in all most cell types, making it an unspecific biomarker of cell damage anywhere in the body, and its level increases within minutes of a cell's entering a hypoxic-ischemic state. $\mathrm{LDH}$ has proven more valuable as prognostic biomarker for sepsis as elevated LDH levels have been associated with high mortality in several studies $[\mathbf{2 3 , 2 4 ]}$ While study by Zein et al. [25] reported increased serum LDH levels are commonly occurred in patients with severe sepsis and consider as a marker of cell injury that reflects the degree of tissue damage also Lu et al. [26] revealed elevated LDH was associated with 28-day mortality in patients with sepsis.

The present study showed positive correlation between serum LDH levels at admission and duration of hospital stay that in agreement with study by Halden et al. [4] that suggested early elevated LDH levels in children with suspected sepsis are associated with mortality, organ dysfunction and prolonged length of hospital stay.

Our study showed statistically significant correlation between lactate dehydrogenase $(\mathrm{LDH})$ at admission and hemoglobin, granulocyte / lymphocyte ratio, total leucocytic count (TLC), creatinine $(\mathrm{Cr})$, Urea, aspartate transaminase (AST), alanine transaminase (ALT), C-reactive protein (CRP) in cases group.

This can be explained by the level of inflammatory biomarker (CRP) is increasing with the severity of illness, so inflammatory biomarkers can be used as a diagnostic and prognostic factors, level of SGOT which is one of liver enzyme which increase with hepatic dysfunction \& inflammatory cells as staff cell also increase with the severity of illness.

This is in agreement with Hussain and Kim [27] study concluded that CRP is used as one of the markers of choice in monitoring the acute phase response \& McWilliam and Riordan [28] study showed that serial CRP measurement can be used as a diagnostic tool for finding clinical infections, monitoring effects of treatment, outcome, and early detection of relapse of the disease. Also study by Pradhan et al. [29] revealed the value of CRP in predication of patients with suspected sepsis especially who present with the SIRS manifestation. Also, CRP could be very helpful in resource-limited places, where recent biomarkers such as procalcitonin or interleukins unavailable.

Koozi et al. [30] suggested that high CRP level at admission $(>100 \mathrm{mg} / \mathrm{L})$ was associated with an high risk of 30-day ICU mortality as well as prolonged hospital stay in survivors.

Huang et al. [31] showed that: Amount of AST and ALT in the blood is directly related to the extent of the tissue damage. After severe damage, AST levels rise 10 to 20 times and greater than normal, whereas ALT can reach higher levels (up to 50 times greater than normal).

Our study showed statistically significantly elevation in NLR in cases as compared with controls as well as in non-surviving critically ill patients with sepsis and significant positive correlation with LDH at admission. The NLR is a common inflammatory marker, calculated from complete blood cell counts. Zahorec et al. [32] who first used NLR as marker of systemic inflammation and a predictor of critical infections such as bacteremia and sepsis as well as severity of disease.

This is in agreement with Gozdas et al. [33] that suggested higher NLR ratio may be useful in estimating nosocomial sepsis in hospitalized patients also found correlation between increased NLR and CRP elevation at the time of nosocomial sepsis.

Also Naess et al. [34] concluded role of NLR in distinguishing between patients with suspected septicemic bacterial infections from patients with other bacterial infections, as NLR higher in septicemic than non-septicemic patients. Zhang et al. [35] studied the diagnostic role of different hematological parameters in sepsis and suggested that 
value of NLR in predicting sepsis superior to CRP. Also the predictive value of the combination of NLR, platelet distribution width (PDW) and red cell distribution width (RDW) was almost equal to that of procalcitonin. In contrast study by Lowsby et al. [36] that found NLR alone was insufficient in predicting bacteremia as blood cultures were positive in $13.8 \%$ of patients.

Our study showed positive correlation between LDH, pSOFA, $(r=0.785, p=0.000)$ and PRISM III $(r=0.842, p=0.000)$. Similarly, García-Gigorro et al. [37] concluded that SOFA widely used for daily assessing acute morbidity and follow-up critically ill patients in critical care units. This is in agreement with Chkhaidze et al. [38] who observed that pSOFA scores is an excellent tool to assess the extent of organ dysfunction in critically ill patients while PRISM III gives a good rank for diagnosis risk rather than specific organ involvement. This in agreement with study Zhou et al. [39] concluded pSOFA has better predictive value in the outcome of patients with suspected sepsis than PRISM III but studies by suggested that the PRISM III score had good sensitivity and specificity in prediction of mortality in septic patients.

\section{Conclusion:}

Sepsis is one of most common cause of morbidity and mortality in pediatric ICU unless early detected and properly managed. The study suggests that serum LDH a simple and early marker can be a useful in diagnosis and prognosis of patients with suspected sepsis. A future studies on large sample size are required to confirm the precise role of serum LDH in early predication of sepsis especially in limited laboratory facilities hospitals.

\section{References}

1- SINGER M., DEUTSCHMAN C.S., SEYMOUR C.W., SHANKAR-HARI M., ANNANE D., et al.: The Third international consensus definitions for sepsis and septic shock (Sepsis-3) JAMA, 315: 801-810, 2016.

2- GOLDSTEIN B., GIROIR B., RANDOLPH A. and the Members of the International Consensus Conference on Pediatric Sepsis: International pediatric sepsis consensus conference: Definitions for sepsis and organ dysfunction in pediatrics. Pediatr Crit Care Med., 6: 1, 2005.

3- JAVED ISMAIL and JHUMA SANKAR: System inflammatory response syndome (SIRS) and sepsis. An Everevolving Paradigm Indian J. Pediatr., 82 (8): 675-676, 2015.

4- HALDEN S.F., BROU L., DEAKYNE S.J., KEMPE A., FAIRCLOUGH D.L. and BAJAJ L.: Association between early lactate levels and 30-day mortality in clinically suspected sepsis in children. JAMA Pediatrics, 171 (3): 249-55, 2017
5- SINGER A.J., TAYLOR M., DOMINGO A., GHAZIPURA S., KHORASONCHI A., THODE Jr. H.C. and SHAPIRO N.I.: Diagnostic characteristics of a clinical screening tool in combination with measuring bedside lactate level in emergency department patients with suspected sepsis. Academic Emergency Medicine, 21 (8): 853-7, 2014.

6- VINCENT J.L., e SILVA A.Q., COUTO L. and TACCONE F.S.: The value of blood lactate kinetics in critically ill patients: A systematic review. Critical Care, 20 (1): 14, 2016.

7- LONG B. and KOYFMAN A.: Ready for Prime Time? Biomarkers in Sepsis. Emergency Medicine Clinics of North America, 35.1: 109-122, 2017.

8- BAKKER J., NIJSTEN M.W. and JANSEN T.C.: Clinical use of lactate monitoring in critically ill patients. Ann. Intensive Care, 3: 12, 2013.

9- JANSEN T.C., van BOMMEL J., SCHOONDERBEEK F.J., SLEESWIJK VISSER S.J., van der KLOOSTER J.M., LIMA A.P., ET AL.: Early lactate-guided therapy in intensive care unit patients: A multicenter, open-label, randomized controlled trial. Am. J. Respir Crit. Care Med., 182: 752-61, 2010.

10- MARIK P.E. and BELLOMO R.: Lactate clearance as a target of therapy in sepsis: A flawed paradigm. OA Critical Care, 1: 3-8, 2013.

11- GOLDSTEIN S.L., SOMERS M.J., BAUM M.A., SYMONS J.M., BROPHY P.D., BLOWEY D., BUNCHMAN T.E., BAKER C., MOTTES T., MCAFEE N. and BARNETT J.: Pediatric patients with multi-organ dysfunction syndrome receiving continuous renal replacement therapy. Kidney International, 67 (2): 653-8, 2005.

12- BIRON B.M., AYALA A. and LOMAS-NEIRA J.L.: Biomarkers for Sepsis: What is and What Might Be? Biomarker Insights. SAGE J., 10s4: 7-17, 2015.

13- FREUND Y., DELERME S., GOULET H., BERNARD M., RIOU B. and HAUSFATER P.: Serum lactate and procalcitonin measurements in emergency room for the diagnosis and risk-stratification of patients with suspected infection. Biomarkers, 17 (7): 590-6, 2012.

14- ALKHATIB A.J. and ALRAKAF N.A.: Lactate Dehydrogenase: Physiological Roles and Clinical Implications. Clin. Med., 137 (5): 363-9, 2019.

15- AHARON E., SHENTAL O., TCHEBINER J.Z., LAUFER-PERL M., WASSERMAN A., SELLA T. and GUZNER-GUR H.: Diagnostic and prognostic value of very high serum lactate dehydrogenase in admitted medical patients. Isr Med. Assoc. J., 16 (7): 439, 2014.

16- PIERRAKOS C. and VINCENT J.L.: Sepsis biomarkers: A review. Crit Care, 14 (1): R15, 2010.

17- SANKAR V. and WEBSTER N.R.: Clinical application of sepsis biomarkers. J. Anesth., 27 (2): 269-83, 2013.

18- WACHARASINT P., NAKADA T.A., BOYD J.H., RUSSELL J.A. and WALLEY K.R.: Normal-range blood lactate concentration in septic shock is prognostic and predictive. Shock, 38 (1): 4-10, 2012.

19- WASSERMAN A., SHNELL M. and BOURSI B.: Prognostic significance of serum uric acid in patients admitted to the department of medicine. AMJ Med. Sci., 339: 5$21,2010$. 
20- HENDYA R.M., ELAWADYB M.A. and ABD EL KAREEMC H.M.: Role of lactate dehydrogenase and other biomarkers in predicting prognosis of community-acquired pneumonia Egyptian J. of Broncholo., 13 (4): 539-544, 2020.

21- TAPIA P., SOTO D., BRUHN A., ALEGRÍA L., JARUFE N., et al.: Impairment of exogenous lactate clearance in experimental hyperdynamic septic shock is not related to total liver hypoperfusion. Crit Care, 19: 188, 2015.

22- HELLIKSSON F., WERNERMAN J., WIKLUND L., ROSELL J. and KARLSSON M.: The combined use of three widely available biochemical markers as predictor of organ failure in critically ill patients Scandinavian J. of clinical and laboratory investigation, 1-7, 2016.

23- SHAPIRO N.I., HOWELL M.D., TALMOR D., NATHANSON L.A., LISBON A., WOLFE R.E., et al.: Serum lactate as a predictor of mortality in emergency department patients with infection. Annals of Emergency Medicine, 45 (5): 524-8, 2005.

24- MIKKELSEN M.E., MILTIADES A.N., GAIESKI D.F., GOYAL M., FUCHS B.D., SHAH C.V., et al.: Serum lactate is associated with mortality in severe sepsis independent of organ failure and shock. Crit Care Med., 37 (5): 1670-7, 2009.

25. ZEIN J.G., LEE G.L., TAWK M., DABAJA M. and KINASEWITZ G.T.: Prognostic significance of elevated serum lactate dehydrogenase $(\mathrm{LDH})$ in patients with severe sepsis. Chest, 126 (4): 873S, 2004.

26- LU J., WEI Z.H., JIANG H., CHENG L., CHEN Q.H., CHEN M.Q., et al.: Lactate dehydrogenase is associated with 28-day mortality in patients with sepsis: A retrospective observational study. J. Surg. Res., 228: 314-321, 2018.

27- HUSSAIN T.M. and KIM D.H.: C-reactive protein and erythrocyte sedimentation rate in orthopaedics. Spring, 15: 13-6, 2002.

28- McWILLIAM S. and RIORDAN A.: How to use: Creactive protein. Arch. Dis. Child Educ. Pract Ed., 95 (2): $55-58,2010$.

29- PRADHAN S., GHIMIRE A., BHATTARAI B., KHANAL B., POKHAREL K., LAMSAL M. and KOIRALA S.: The role of C-reactive protein as a diagnostic predictor of sepsis in a multidisciplinary Intensive Care Unit of a tertiary care center in Nepal. Indian J. Crit Care Med., 20: 417-20, 2016.
30- KOOZI H., LENGQUIST M. and FRIGYESI A.: Creactive protein as a prognostic factor in intensive care admissions for sepsis; A Swedish multicenter study. Journal of Critical Care, 56: 73-79, 2020.

31- HUANG X.J., CHOI Y.K., IM H.S., YARIMAGA O., YOON E. and KIM H.S.: Aspartate Aminotransferase (AST/GOT) and Alanine Aminotransferase (ALT/GPT) Detection Techniques. Sensors (Basel), 6 (7): 756-782, 2006.

32- ZAHOREC R.: Ratio of neutrophil to lymphocyte countsrapid and simple parameter of systemic inflammation and stress in critically ill. Bratislavske lekarske listy, 102 (1): 5-14, 2001.

33- GOZDAS H., GEL K., TURKEN E., YASAYACAK A., KESGIN M. and AKDENIZ H.: The role of hematological parameters in estimating nosocomial sepsis Electron J. Gen. Med., 16 (3): 139, 2019.

34- NAESS A., NILSSEN S.S., MO R., EIDE G.E. and SJURSEN H.: Role of neutrophil to lymphocyte and monocyte to lymphocyte ratios in the diagnosis of bacterial infection in patients with fever. Infection, 45: 299-307, 2017.

35- ZHANG H.B., CHEN J., LAN Q.F., MA X.J. and ZHANG S.Y.: Diagnostic values of red cell distribution width, platelet distribution width and neutrophil-lymphocyte count ratio for sepsis. Exp. Ther. Med., 12: 2215-9, 2016.

36- LOWSBY R., GOMES C., JARMAN I., et al.: Neutrophil to lymphocyte count ratio as an early indicator of blood stream infection in the emergency department. Emerg. Med. J., 32: 531-4, 2015.

37- GARCÍA-GIGORRO R., SÁEZ-de la FUENTE I., MARÍN MATEOS H., ANDRÉS-ESTEBAN E.M., SANCHEZIZQUIERDO J.A. and MONTEJO-GONZÁLEZ J.C.: Utility of SOFA and -SOFA scores for predicting outcome in critically ill patients from the emergency department. Eur. J. Emerg. Med., 26 (4): 309-310, 2019.

38- CHKHAIDZE M.G., KHELADZE Z.S., PRUIDZE D.R., ABELASHVILI D.I. and GVETADZE P.R.: Comparison of PIM and SOFA scoring systems for mortality risk prognosis in critically ill children with sepsis. Georgian Med. News, 131: 66-68, 2006.

39- ZHOU L.B., CHEN J., DU X.C., WU S.Y., BAI Z.J. and LYU H.T.: Value of three scoring systems in evaluating the prognosis of children with severe sepsis. Zhongguo Dang Dai Er Ke Za Zhi, 21 (9): 898-903, 2019. 


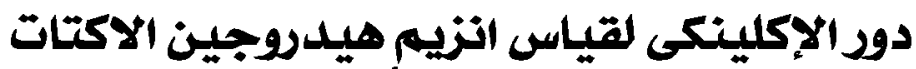

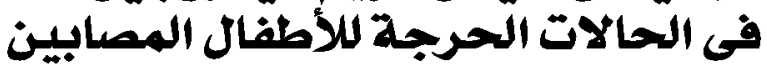

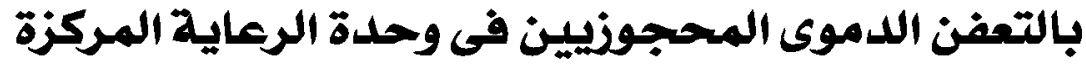

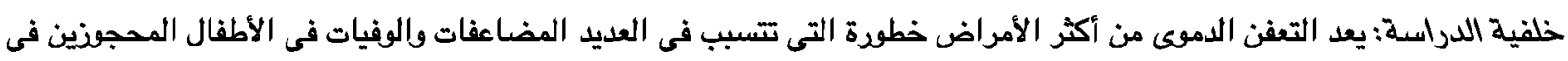

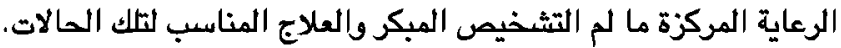

الهدف من الدراسـة: تقييم دوف انزيم نازع هيدرو جين الإكتات فى التبئ بحالات التعفن الدموى فى الصالات الصرجة للأطفال المحجمنين

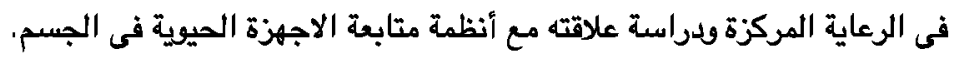

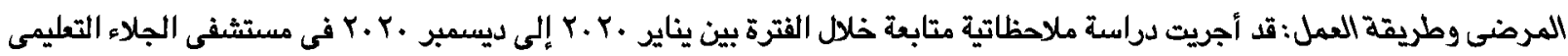

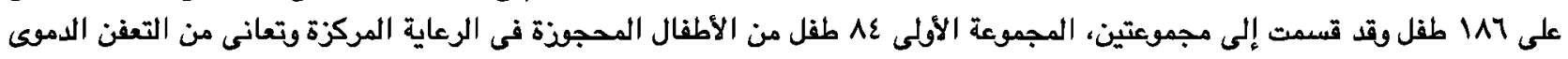
والمجموعة الضابطة تتكون من عی طفل الحالات المستقرة المحجوذة في قسم الأطفال.

النتائج: وقد وجد أن نسبة انزيم نازع هيدرجين الاكتات مرتفعة فى مجموعة الحالات الحرجة عن المجموعة الضابطة وآيضاً فى حالات

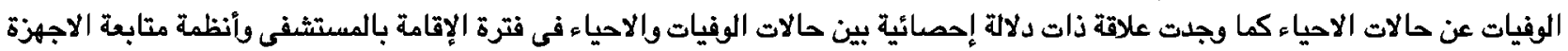
الحيوية في الجسم. وقد وجلت علا قة ذات دلالة إحصائية إيجابية بين انزيم نازع هيدرجين الاكتات وأنظمة متابعة الاجهزة الحيوية في الجسم. الاستتاج: يمكن استخدام انزيم نازع هيدرجين الاكتات كمئشر اللتنبئ بحالات التعفن الدمىى للحالات الحرجة للأطفال المحجونين فى 